\title{
Conjuntive use planning of surface and ground water resources
}

\section{K. Kishan and H.V. Hema Kumar}

See end of the Paper for authors' affiliation

Correspondence to :

\section{K. Kishan}

Department of Soil and Water

Engineering, College of

Agricultural Engineering,

Bapatla (A.P.) India

Email: kishancae@gmail.com
- KEY WORDS : Water, Agiculture, Policy, Food supply

- HOW TO CITE THIS PAPER : Kishan, K. and Hema Kumar, H.V. (2020). Conjuntive use planning of surface and ground water resources . Internat. J. Agric. Engg., 13(1) : 137-144, DOI: 10.15740/HAS/IJAE/13.1/137-144. Copyright@2020: Hind Agri-Horticultural Society. 